
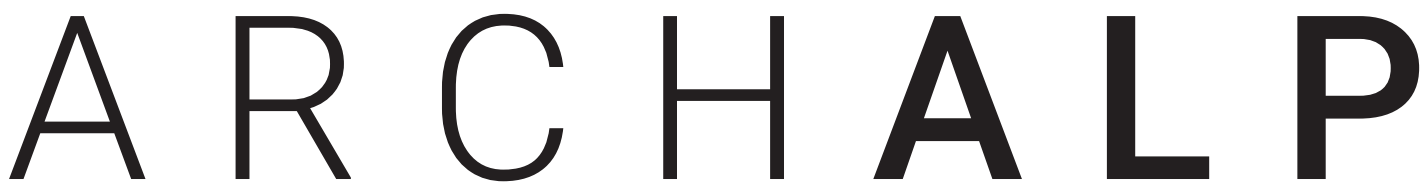

Rivista internazionale di architettura e paesaggio alpino / Revue internationale d'architecture et de paysage dans les Alpes / Internationale Zeitschrift für Alpine Architektur und Landschaft / Revija za alpsko arhitekturo in pokrajino / International journal of alpine architecture and landscape

Rer una nuota abitabilita delle Alpi.

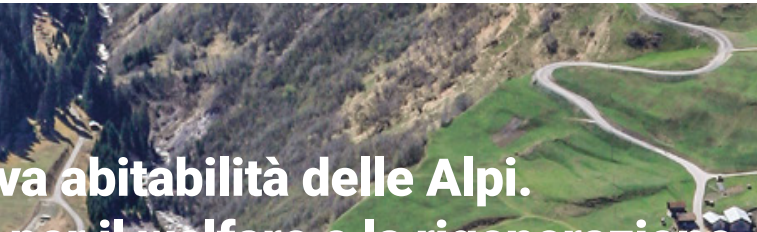
Architeture pet ilf lfare e la rigenerazione For a new inhabifability of the Alps. Architectures for welfare ând regeneration $/$ Pour une nouvelle habitabilité des Alpes. Architectures pour le welfare et la régéhérationy Für eine núue Bewohnbarkeit in den Alpen. Architekturen für Wohf ahrt und Regeneration / Za novo. bivalnost v Alpah, arhitekture za dobrobit in regeneracijo
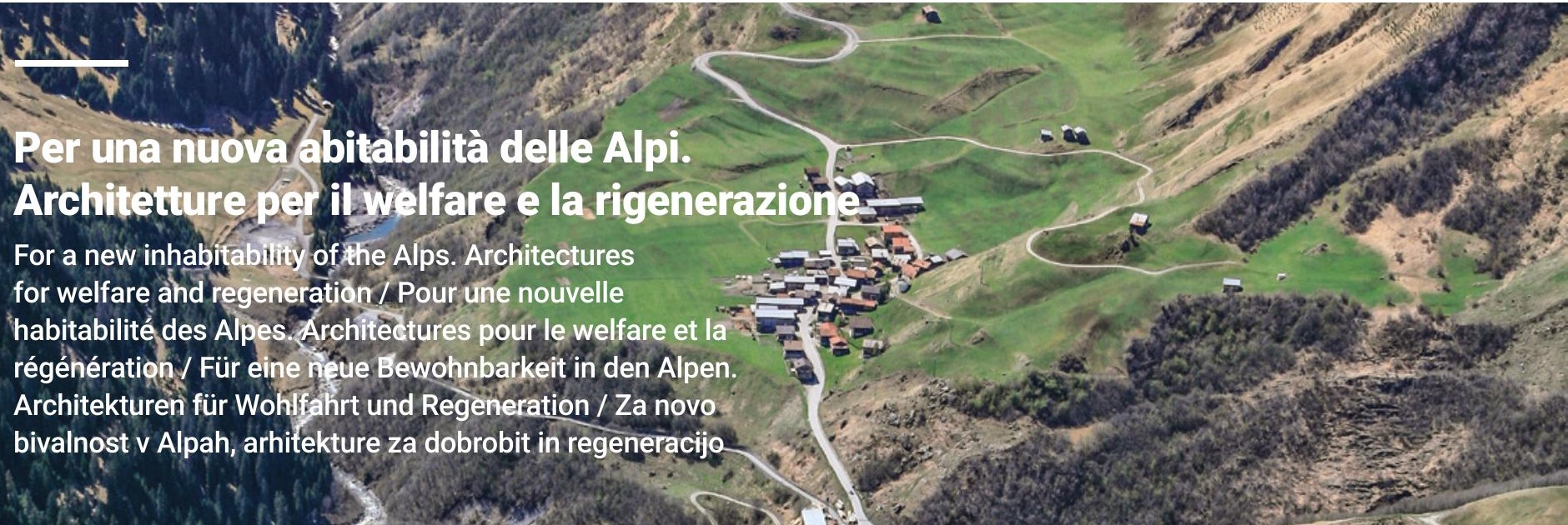
a $x \rightarrow 3$
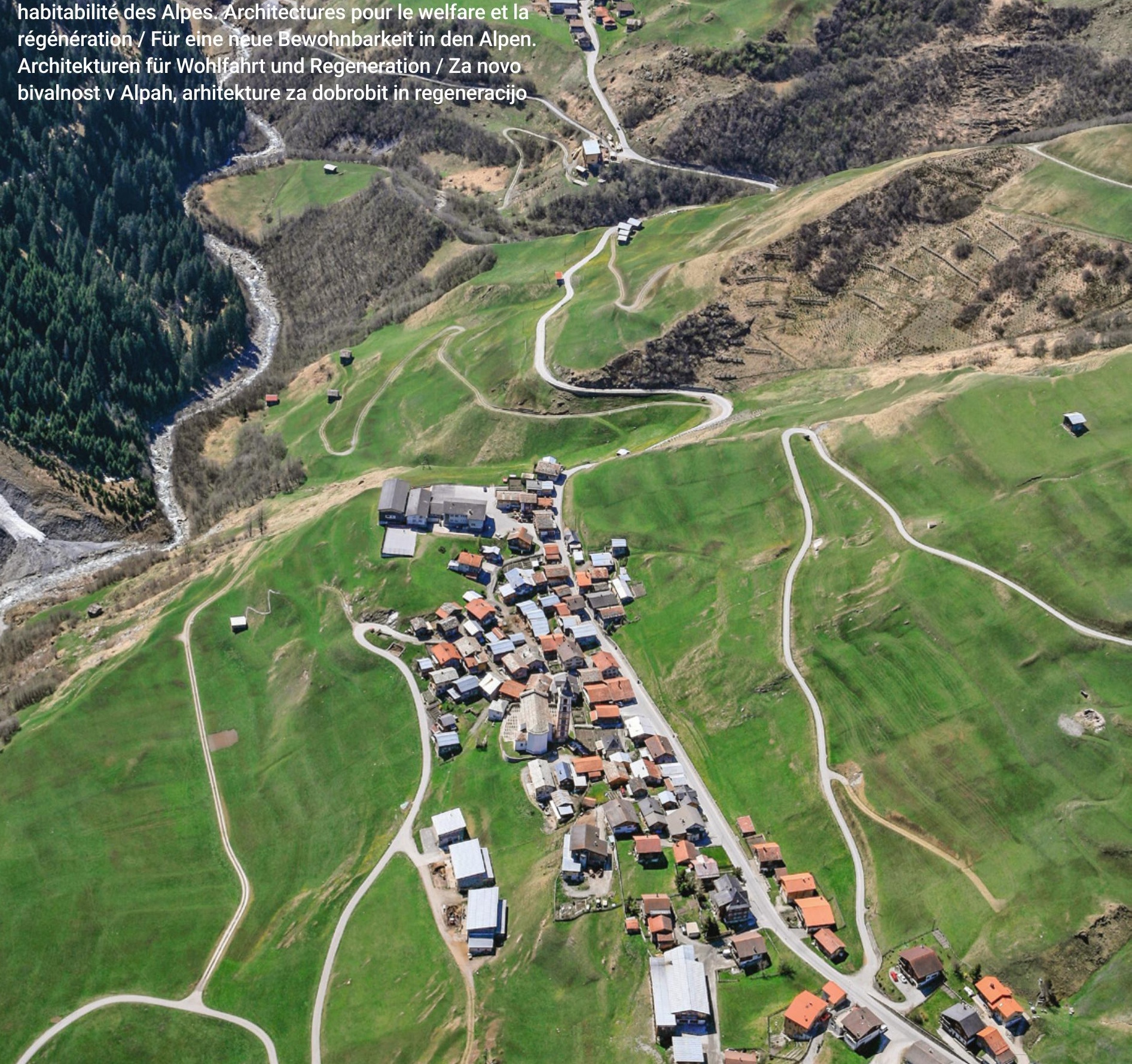


\section{Indice dei contenuti Contents}

\section{Temi}

Sulla centralità di spazio e territorio nel progetto di rigenerazione delle montagne e delle aree interne / On the centrality of space and territory in the project of regeneration of mountains and internal areas Antonio De Rossi, Laura Mascino

I servizi nelle Alpi italiane: quali e dove? Idee per uno scenario post-pandemico / Facilities in the Italian Alps: which ones and where? Ideas for a post-pandemic scenario

Giuseppe Dematteis

Manifesto di Camaldoli per una nuova centralità della montagna

Alla ricerca della distanza perduta. Rigenerare luoghi, persone e immaginari del riabitare alpino / In search of the lost distance. Regenerating places, people and images related to Alpine reinhabitation

Filippo Barbera, Andrea Membretti

Futuro e rigenerazione

Marco Bussone

\section{Esperienze}

Dorferneuerung zwischen Erhalten und Gestalten / 
Valades ousitanes, architettura e rigenerazione / Valades ousitanes,

Ostana e Topolò: hardware, software e welfare nelle comunità di "ritorno" / Ostana and Topolò: hardware, software and welfare in "return" communities

Margherita Valcanover

"Senza mostrare i muscoli": i progetti di rigenerazione di Tao+C e AZL nel solco della "prosperosa società" della Cina contemporanea / "Without flexing one's muscles": the regeneration projects of Tao+C and AZL in the wake of the "prosperous society" of contemporary China Edoardo Bruno, Dalila Tondo

L'archipel Butor. Une régénération, par la culture, d'un village soumis à la métropolisation genevoise / The Butor archipelago. A regeneration, through culture, of a village subject to the metropolisation of Geneva Arnaud Dutheil

Pratiche e progettualità di rigenerazione e welfare: il "Premio triennale Giulio Andreolli - Fare paesaggio" / Actions and projects of regeneration and welfare: the "Premio triennale Giulio Andreolli - Fare paesaggio" Giorgio Tecilla

Architetture e strategie per il welfare. Il caso di Brunico in Val Pusteria / Welfare architectures and strategies. The Bruneck case in Val Pusteria

Eleonora Gabbarini

Arhitektura oživlja / Architecture revives Kristina Dešman, Maja Ivanič

Si Crans-Montana meurt. Soigner le corps malade d'une station / If Crans-Montana dies. Taking care of the ailing body of a tourist resort Patrick Giromini 


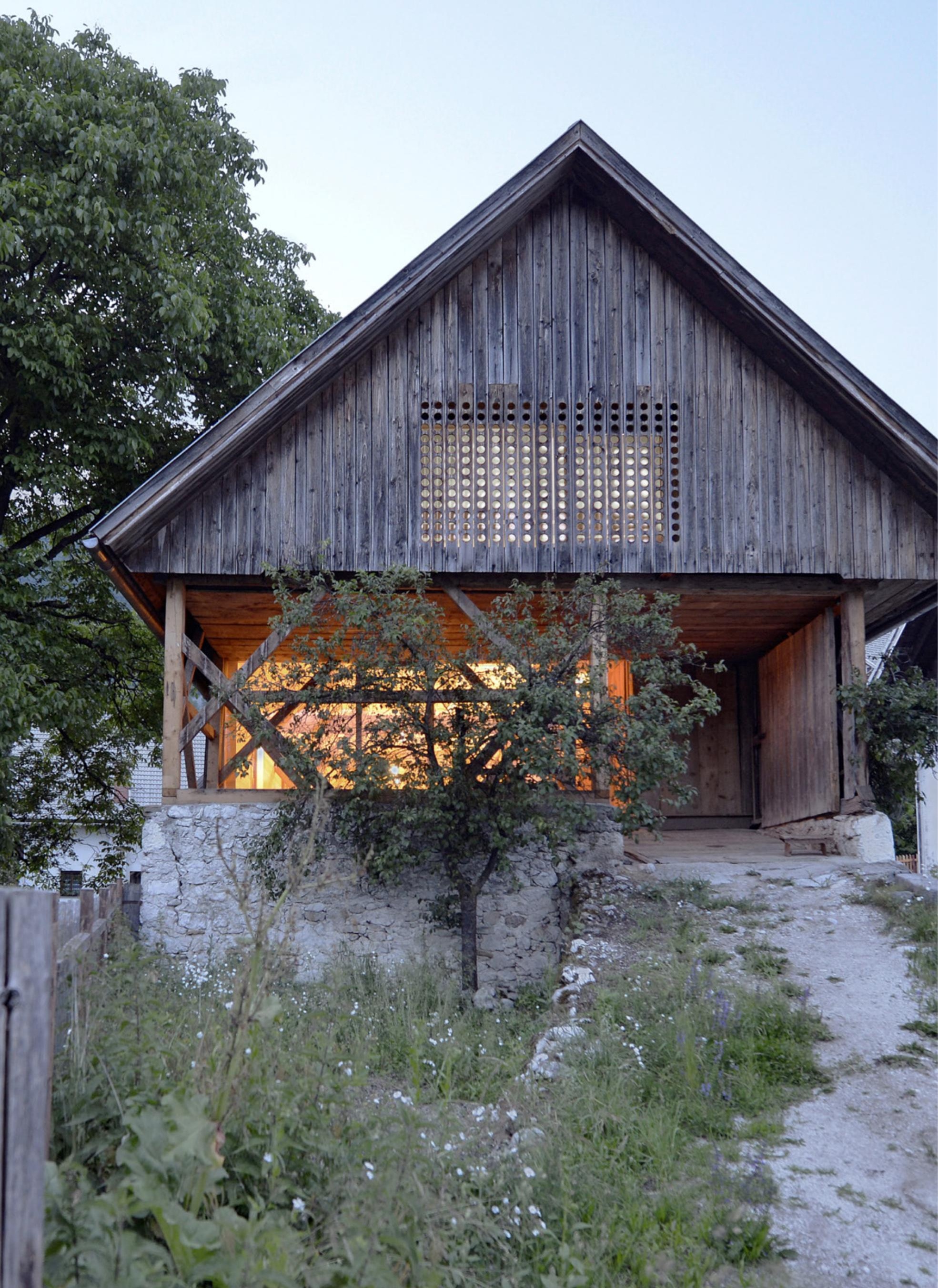




\title{
Arhitektura oživlja
}

\author{
Architecture revives
}

\begin{abstract}
Slovenia is an Alpine country: 11 percent of its territory is above 1,600 meters above sea level. The Slovenian Alps are dotted with secluded farms and clustered hamlets, but there are also larger towns on the plains of the pre-Alpine regions. In the 1990s Slovenia, together with other Alpine countries, entered the Convention on the Protection of the Alps. Due to its small size, the Slovenian Alpine area is manageable, but very fragile and sensitive to various interventions, especially to architectural ones. Namely, architecture shapes the mentality and consciousness of people, and thus also a country's cultural and economic development. Today, it is difficult to talk about revitalizing the Alps without mentioning tourism, which brings money to the Alpine environment and creates jobs. Unfortunately, the Slovenian Alpine space is changing without a comprehensive approach to urban and architectural development. Economy and tourism-oriented strategies are also vague. Individual examples of modern quality architecture are a rather happy coincidence, the result of the architect's sensibility, experience and mastery, and of the investor's cultural vision. That is why the examples of good architectural practice that culturally and economically revive the Slovenian Alpine region and preserve its identity stand out all the more. They are distinguished by their attitude towards the environment - marked by an understanding and respect for the natural and cultural landscape, dimensions of volumes that are carefully integrated into the scenography of mountain ambiances, modern spatial design, the selection of new natural materials, the interpretation of traditional architectural heritage, and preservation of local traditions and the knowledge of ancestors.
\end{abstract}

\section{Maja Ivanič}

Architect practicing in Slovenia, she is active in several architecture award events and conferences, such as Piran Days of Architecture and Piranesi Award (2005-2007) as president, the Mies van der Rohe Award as member of the Advisory Committee of European Union Prize for Contemporary Architecture (since 2014) and the Slovak architectural Award ARCH as member of the jury (2019). She also served as Editor-in-chief of Hiše magazine (2005-2008). Specialized in architecture of kindergartens and schools, she and her co-authors received the Golden Pencil Award for the kindergarten Pedenjcarstvo in Ljubljana.

\section{Kristina Dešman}

Architecture critic and researcher, she also writes for several architectural magazines, and is currently member of the editorial board of Hiše (editor-in-chief) and Architect's Bulletin $a b$ (technical editor). She is curator of several architectural exhibitions showcasing Slovenian architecture across the country and abroad. She was member of the executive board of the Association of Architects of Ljubljana DAL (2014-2019). She was also initiator of the Open House Slovenia in 2010 and project leader until 2018. The project received the Plečnik Medal in 2012 for its contribution to architectural culture.

\section{Keywords}

Slovenia, development, revitalizing, heritage, strategies. 
$\mathrm{Na}$ odprtju Prenova alpskega skednja / Alpine Barn Renovation, Bohinj, 2015 (foto Tomaž Gregorič).
Slovenija je alpska dežela: 11 odstotkov njenega ozemlja je nad 1600 metri nadmorske višine. Naravno in družbeno pa so z njim povezana širna območja predalpskega hribovja. Slovenske Alpe so najjužnejši krak obsežnega sistema Alp. So nižje, raztezajo se na manjši površini, njihova posebnost pa je bela barva kamna. Posejane so s samotnimi kmetijami in gručastimi zaselki, na ravninah predalpskih pokrajin pa so večja mesta. V 90. letih prejšnjega stoletja je Slovenija skupaj z ostalimi alpskimi deželami pristopila $\mathrm{k}$ mednarodni konvenciji o varstvu Alp. Območje alpske konvencije zavzema 33,4 odstotka slovenskega ozemlja, vključuje 62 občin, predstavlja življenjski prostor za 365.000 prebivalcev, pomemben pa je tudi šir- še, saj ljudje v njem iščejo priložnost za zaposlitev, predvsem pa oddih, sprostitev, šport in rekreacijo. Alpe - gore so poseben svet, z zahtevnimi naravnimi, topografskimi, klimatskimi pogoji ter zgodovinskimi, etnološkimi in kulturnimi značilnostmi. Nekoč so bile prostor vernakularnega stavbarstva, ki se je skozi čas prilagajalo svojemu okolju in oblikovao identiteto posameznih alpskih regij. Načrtovane arhitekture, kot jo razumemo danes, v Alpah skoraj ni bilo.

Slovenski alpski prostor je zaradi svoje majhnosti obvladljiv, vendar zelo krhek in občutljiv na različne intervencije, posebej prostorske. Arhitektura namreč usmerja miselnost in zavest ljudi, s tem pa tudi kulturni in gospodarski razvoj. Kakovostno

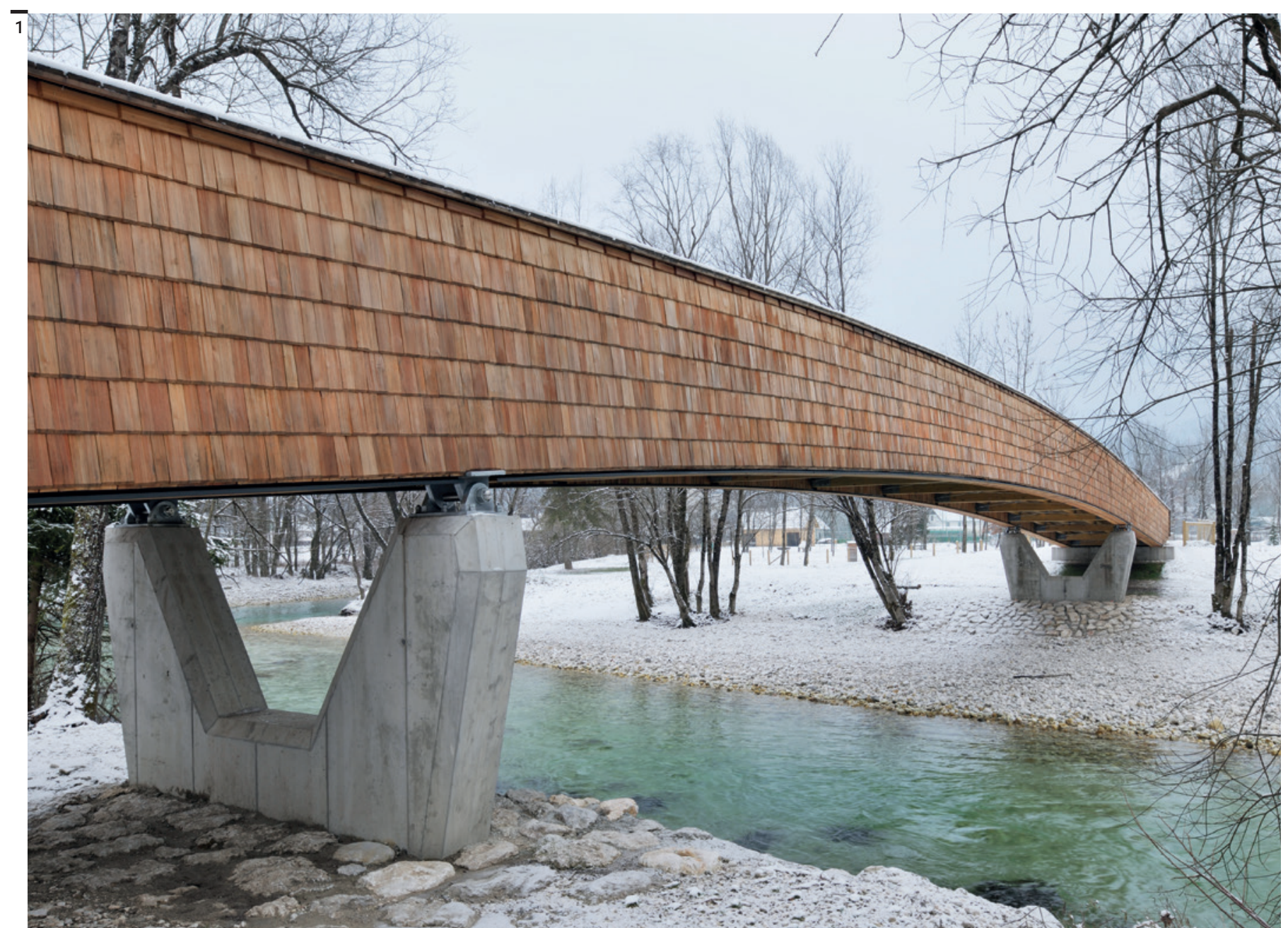


oblikovan in urejen prostor oblikuje boljšo družbo in boljšo prihodnost.

Danes težko govorimo o oživljanju Alp brez omembe turizma, ki prinaša v alpsko okolje denar in odpira delovna mesta. Zelo vpliva na gradbene aktivnosti, posledično pa tudi na videz krajine ter na njeno naravno in kulturno identiteto. Zaradi svoje "invazivnosti" je dvorezen: ob pomanjkanju sonaravne in trajnostne naravnanosti hitro preraste $\mathrm{v}$ kulturno in prostorsko onesnaževanje.

Žal se slovenski alpski prostor skupaj s preostankom slovenskega podeželja razvija brez celovite

Fig. 1 Kolesarska pot in brv čez Savo pri kampu Danica v Bohinjski Bistrici / Bicycle and Footbridge over River Sava at Danica Camp, 2013 (foto Miran Kambič)

Fig. 2 Kolesarska pot Bohinj / Cycling Path Bohinj, 2011

(foto Aleksander S. Ostan). urbanistične in arhitekturne razvojne usmeritve. Nedorečene so tudi gospodarsko-turistične strategije. Posamezni primeri sodobne kakovostne arhitekture so bolj srečno naključje sovpadanja arhitektove občutljivosti, izkušenosti in mojstrstva ter investitorjeve kulturne širine. Večina novogradenj pa ne razume in/ali ne spoštuje danosti in priložnosti alpskega konteksta.

Središča slovenskih alpskih krajev in vasi kličejo po načrtovanem urejanju in prostorskem osrediščenju s kakovostno arhitekturo ali arhitekturno prenovo, ki bi jim zagotovila identiteto in težiščno točko, s tem pa spodbudila tudi trajnostni razvoj kulturnih in gospodarskih potencialov. Več pozornosti bi si zaslužila tudi dotrajana ali sploh neobstoječa infrastruktura. Trenutno stanje je v veliki meri posledica brezbrižnosti politike do celovite prostorske oziroma razvojne strategije, posledica desteletij zanemarjanja obstoječega stavbnega fonda in dopuščanje samograditeljstva, ki ob strokovnem neznanju tudi ne upošteva naravnih, kulturnih, klimatskih in materialnih danosti Alp.

Zato toliko bolj izstopajo primeri dobre arhitekturne prakse, ki oživljajo slovensko alpsko regijo.

V Galeriji DESSA (Ljubljana, Slovenija) smo v zadnjih letih pripravili več dogodkov in razstav, povezanih s tematiko alpske arhitekture. Skozi dobre arhitekturne prakse smo želeli širši in strokovni javnosti predstaviti modele oziroma strategije arhitekturnega razvoja alpske regije. Z nedavno razstavo Galerije Dessa, Slovenska alpska arhitektura 2008-2018 (odprtje februar 2018, razstava še vedno potuje po Sloveniji in Italiji) smo predstavili trideset kakovostno izstopajočih projektov $\mathrm{v}$ Slovenskih alpah. Deset programsko in oblikovno različnih projektov, ki spodbujajo in oživljajo različna področja življenja - bivanje, delo, kulturo in šport - predstavljamo v nadaljevanju. Izbrane projekte odlikuje odnos do okolja, razumevanje

\section{$\overline{2}$}

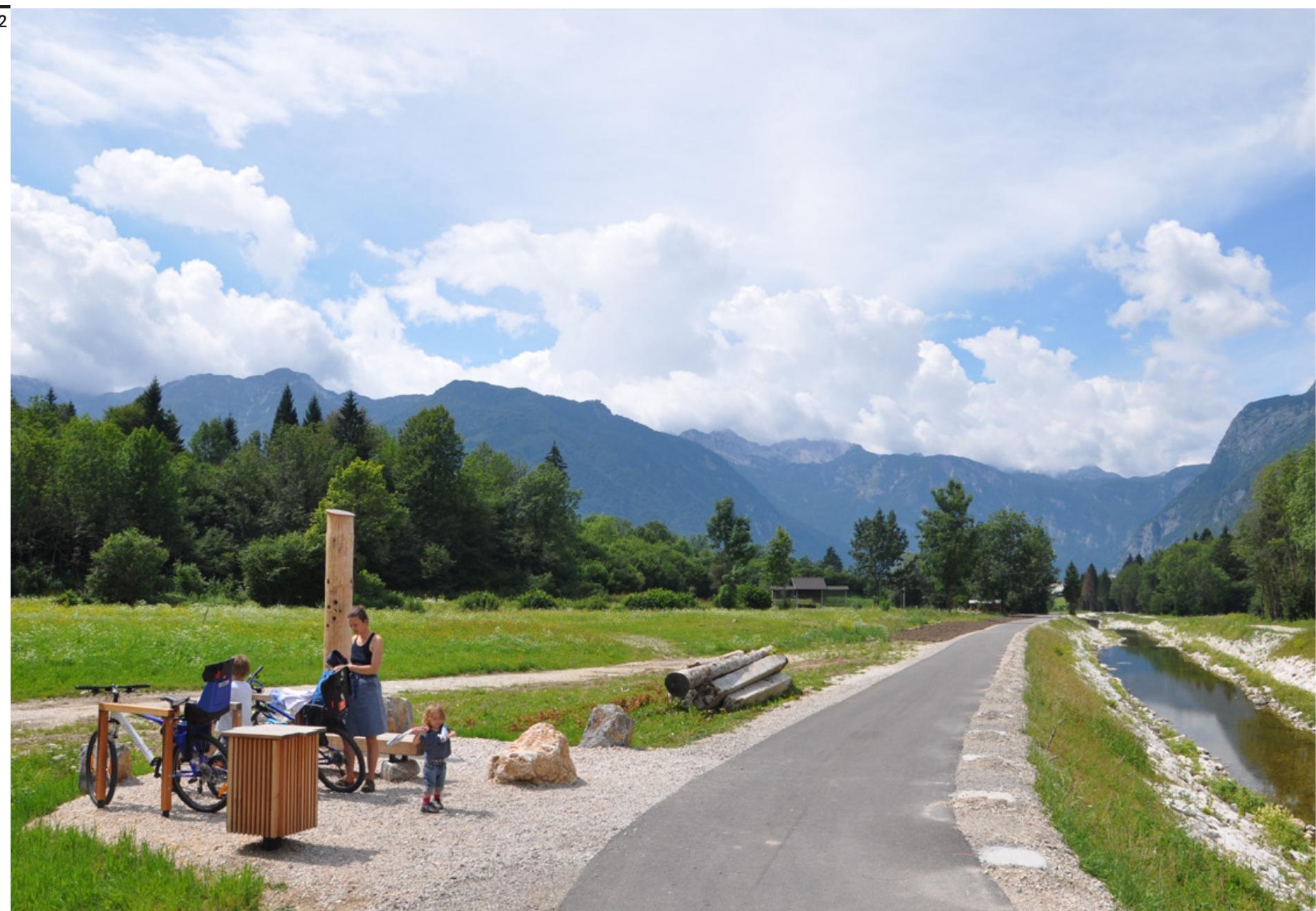


in spoštovanje naravne in kulturne krajine, gabariti, po velikosti in obliki skrbno vpeti v scenografijo gorskih ambientov, kakovostne prostorske in tlorisne zasnove, ki omogočajo sodoben način bivanja, izbor naravnih in naravno razgradljivih sodobnih materialov (les se pojavlja v kominaciji z vidnim betonom, kovino, steklom, kamnom), interpretacija tradicionalne stavbne dediščine, nenazadnje pa tudi ohranjanje lokalne tradicije ter znanja in dognanj naših prednikov.

Arhitektura ni panaceja. A v povezavi z usklajenim trudom skupnosti - z gospodarstvom, turizmom, športom ... vsekakor oživlja.

\section{Odprti prostor / open space}

Kolesarska pot in bro čez Savo pri kampu Danica v Bohinjski Bistrici / Bicycle and Footbridge over River Sava at Danica Camp, 2013

Arhitektura: Dans arhitekti: Rok Bogataj, Miha Dešman, Eva Fišer Berlot, Vlatka Ljubanović, Katarina Pirkmajer Dešman

Atraktivna lesena kolesarska brv čez Savo pri Bohinjski Bistrici je del turističnih kolesarskih poti bohinjske regije. $\mathrm{V}$ prostoru je vzpostavila pot tam, kjer je prej ni bilo. Lepljena nosilca iz smrekovega lesa sta hkrati ograja brvi. Zaščitena sta z oblogo iz macesnovih desk ter skodel, zloženih na tradicionelen način.

Kolesarska pot Bohinj / Cycling Path Bohinj, 2011 Arhitektura: Atelje Ostan Pavlin: Aleksander S. Ostan, Nataša Pavlin

Bohinjska kolesarska pot povezuje Zgornjo in Spodnjo Bohinjsko dolino in privablja aktivne in rekreativne kolesarje. Arhitekti so v smislu trajnostnega vidika reciklaže traso speljali po starih poljskih in gozdnih poteh ter povezali skrita naselja in naravne ambiente. Ob poti so na zanimivih mestih počivališča $\mathrm{z}$ raznoliko arhitekturno opremo, narejeno po tradicionalnih principih iz lokalnega lesa, kamna in jekla.

\section{Športni objekti / sports facilities}

Veslaški center in ciljna regatna arena z novim sodniškim stolpom / Rowing Centre and Regatta Finish Arena with a new Referee Tower, Velika Zaka, Bled, 2010

Arhitektura: Sandra Banfi Škrbec, Miha Kajzelj, Iztok Kavčič, Iztok Lemajič

Trinivojski sodniški stolp se s svojim podolgovatim transparentnim volumnom in crnimi nosilnimi stebri prepleta $\mathrm{z}$ drevjem priobalnega gozda. Nad jezerom lebdijo zamaknjene etaže plošče in ponazarjajo položaj veslaških čolnov v ciljni liniji regatne proge. Celovita ureditev okolice spominja na obstoječe, škarjasto razprte pomole.
Nordijski center Planica: krajinska ureditev / Planica Nordic Centre: Landscape Architecture, Rateče, 2015

Krajinska arhitektura: Studio AKKA: dr. Ana Kučan, Luka favornik

Gorski okvir s Planico, nacionalnim ponosom Slovenije, zaradi svoje naravne dinamike ne potrebuje dodatnih prostorskih poudarkov. Pahljačasta zasnova skakalnic, urejenih po inženirski in programski logiki, je prepoznavna, a v svoji zadržanosti neločljivo vsidrana $\mathrm{v}$ spektakularno dolino na robu Triglavskega narodnega parka.

Nordijski center Planica: skakalnice, spremljajoči in športni objekti / Planica Nordic Centre: Ski Jumps, Auxiliary and Sports Facilities, Rateče, 2015

Arhitektura: Studio Abiro

Natančno načrtovanje topografije, premišljena izbira in omejitve materialov, pogumne podobe in oblike skakalnic in spremljevalnih objektov se ujemajo z navdihujočimi silhuetami gora ter z umir-

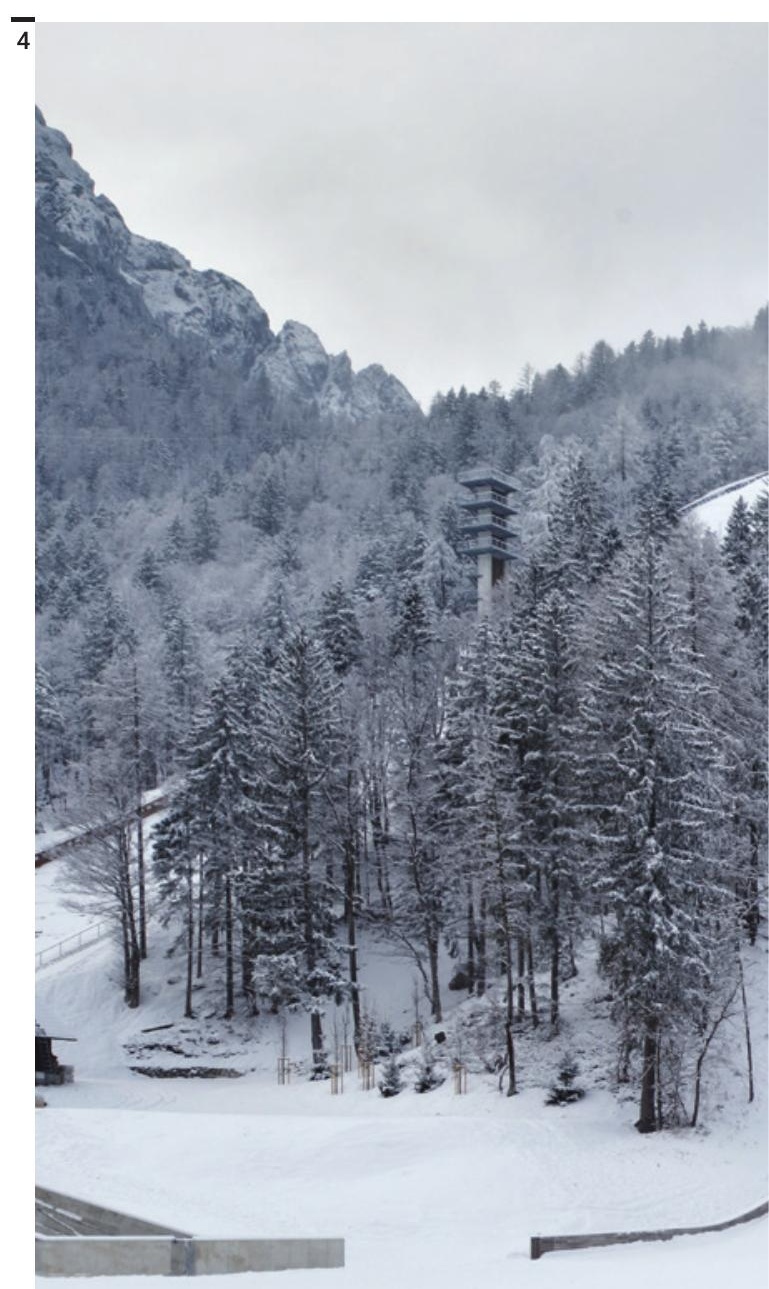



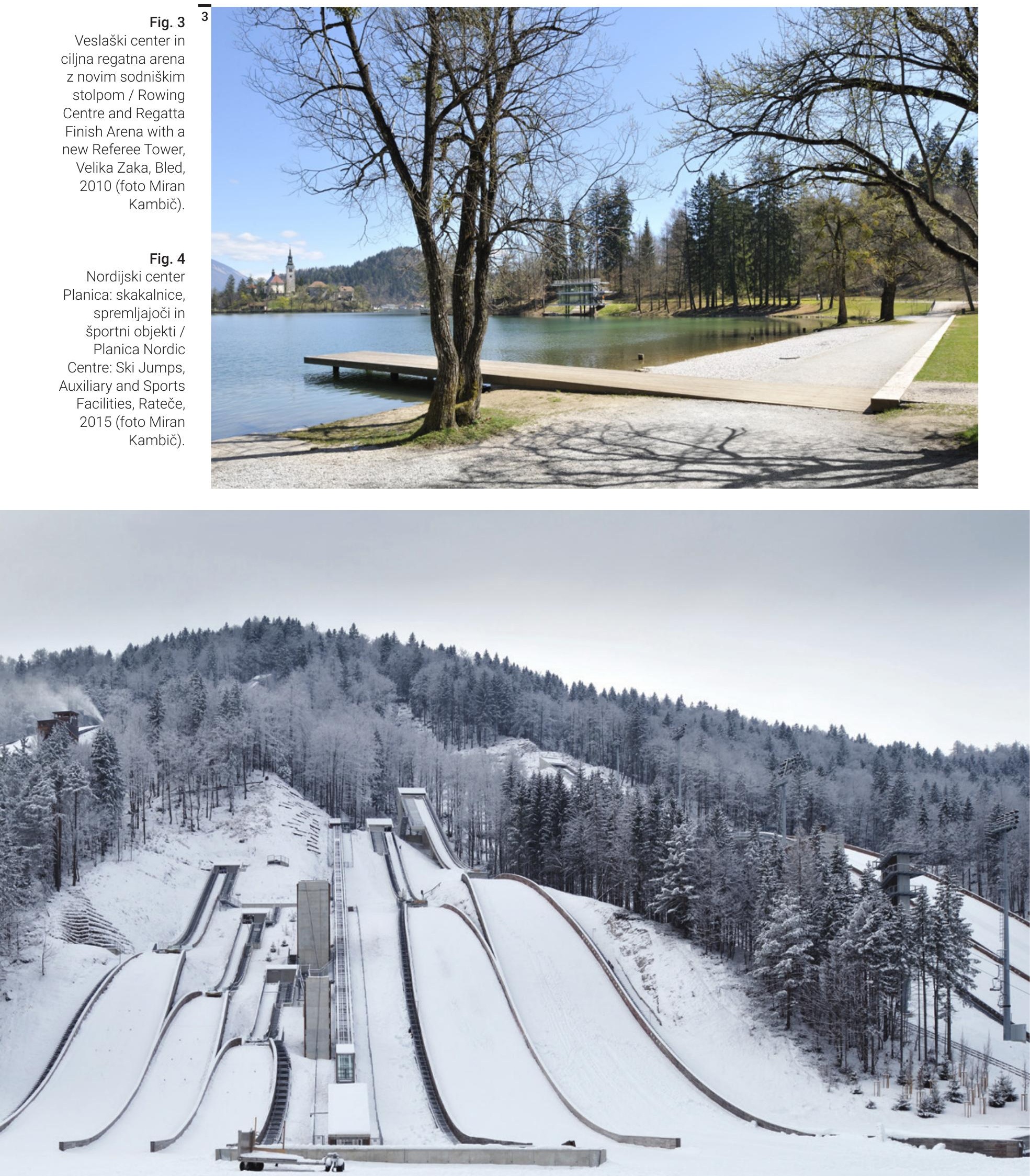
jajočimi borovimi in smrekovimi gozdovi. Ko občutljivo dolino Planice obišče 15.000 obiskovalcev, arhitekturna oblika preneha obstajati, glavno vlogo pa prevzame njena uporabna stran.

\section{Turistični objekti / tourism facilities}

Prenova pastirskega stanu / Renovation of a Shepherds' Cottage, Planina Laška Seč, 2014

Arhitektura: Studio Dom: Maja Evelyn Kristan

Pastirski stan z mlekarno in sirarno ter petimi hlevi na 1.000 metrih nadmorske višine je že več stoletij zatočišče pastirjem in pašni živini. Prenova, ki se je začela na pobudo pašne skupnosti, potekala pa v izvedbi lokalnega mojstra Metoda Kavčiča, ohranja starožitnosti planinskih objektov, uporab-

Fig. 5 Prenova pastirskega stanu / Renovation of a Shepherds'

Cottage, Planina

Laška Seč, 2014

(foto Andrejka

Ščukovt, Maja Evelyn

Kristan, Miljko Lesja).

\section{Javne stavbe / public buildings}

Slovenski planinski muzej / Slovenian Alpine Museum, Mojstrana 2009

Arhitektura: Boris Leskovec, Alja Vehovec, Rok Kajtna
Muzej stoji v ruralnem okolju vasice Mojstrana, ob cesti v ledeniško dolino Vrata. Njegova urbanistična zasnova povzema členjenost obstoječega naselja ter vzpostavlja dialog z grajenim in naravnim okoljem. Nepravilna geometrijska oblika spominja na skalno gmoto. Fasada se z rastrom vertikalnih pasov oblikovno navezuje na arhitekturno značilnost visokogorskih planšarskih zavetišč - stanov.

Rinka - Center za trajnostni razvoj Solčavskega / Rinka - Centre for the sustainable development of Solčavsko region, Solčava 2011

Arhitektura: AU arhitekti: Uroš Lobnik, Andreja Podlipnik in Janko Rožič

Center za trajnostni razvoj Solčavskega stoji v središču naselja. V njem so informacijski center, občinski prostori, dvorana, razstavišče, gostišče, prodajalna in stanovanjski enoti. Stavba se s simetrično zasnovo in z oblikovanjem fasadnega plašča prilagaja merilu vaškega središča. Arhitekti so uporabili lokalne materiale, kot sta kamen in macesnov les.

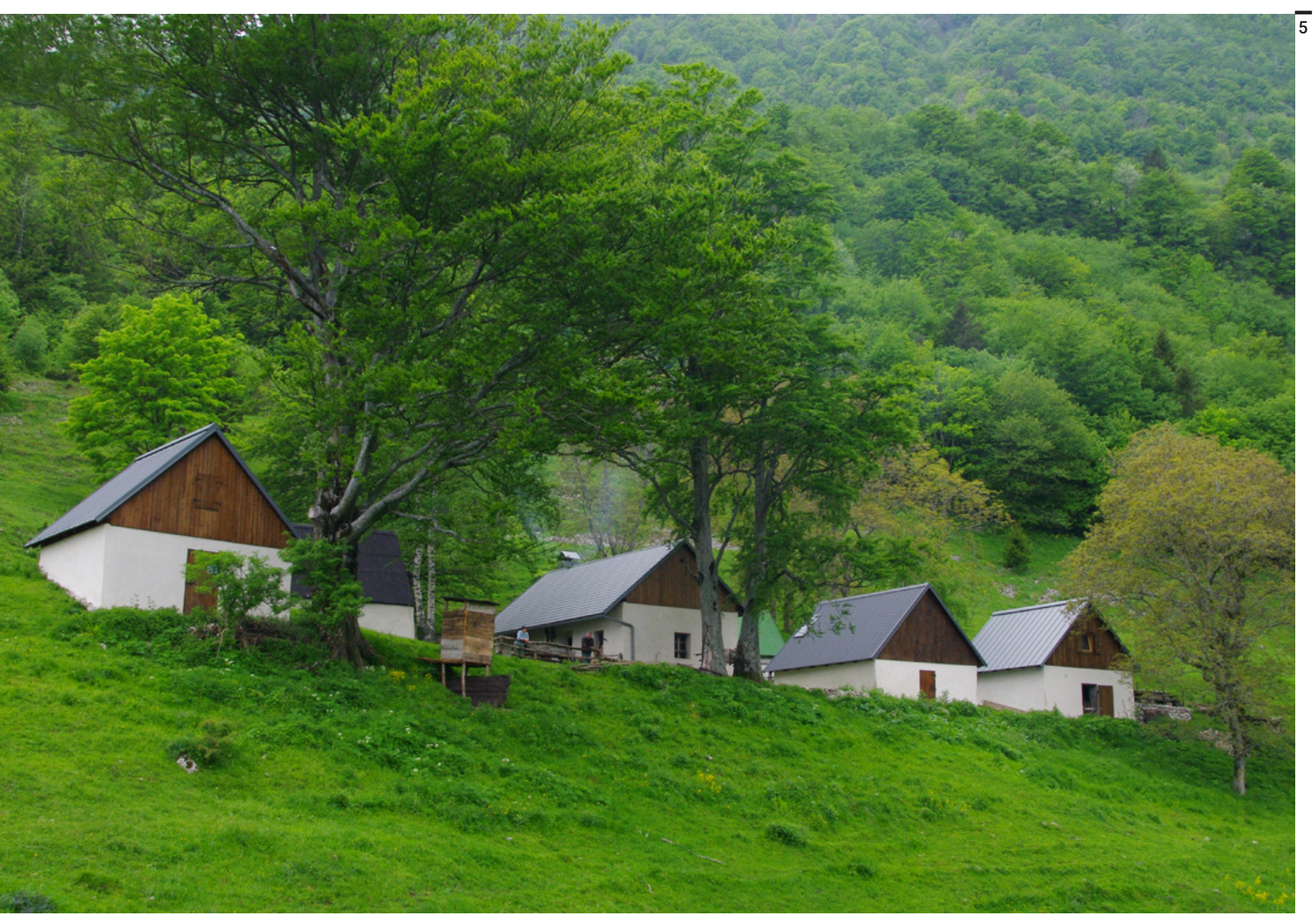




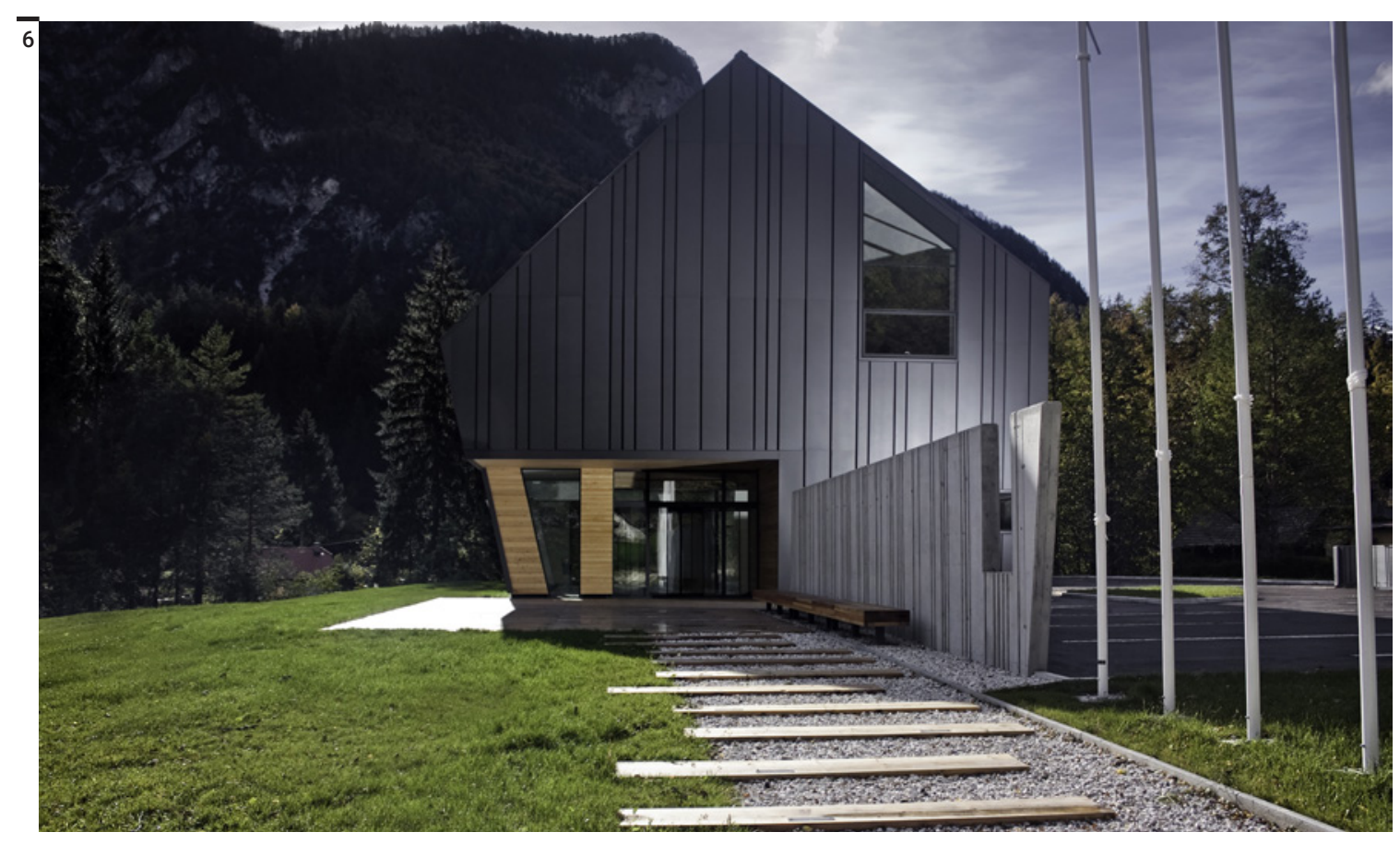

Fig. 6 Slovenski planinski muzej / Slovenian Alpine Museum, Mojstrana 2009 (foto Luka Kaše).

Fig. 7 Rinka - Center za trajnostni razvoj Solčavskega / Rinka - Centre for the sustainable development of Solčavsko region, Solčava 2011 (foto Damjan Švarc, Uroš Lobnik).

$\overline{7}$

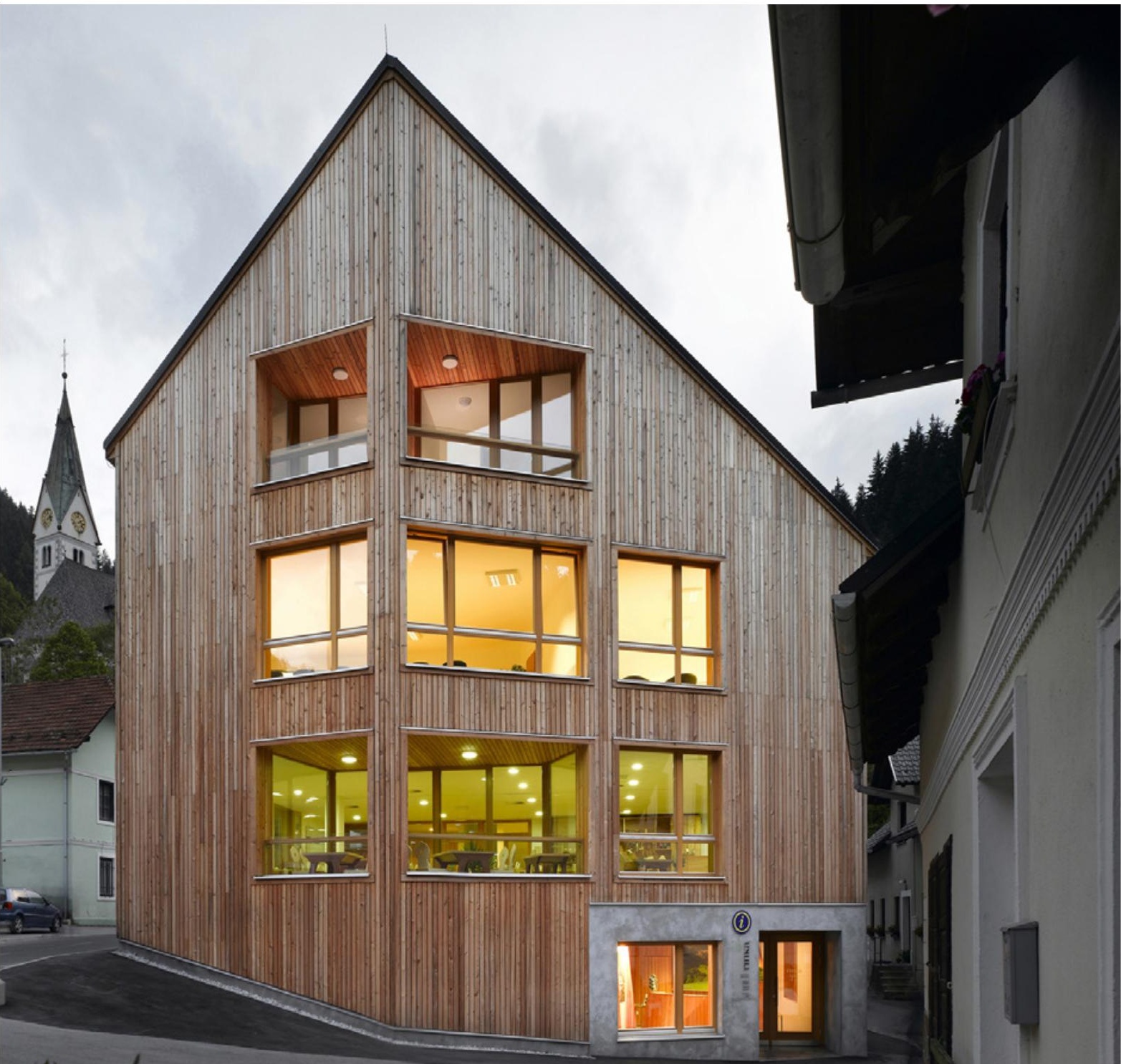


Fig. 8

Hiša v Alpah / House in the Alps, Stara

Fužina, Bohinjsko jezero, 2016 (foto Janez Marolt).

Fig. 9

Prenova domačije Vrlovčnik /

Renovation of Vrlovčnik Homestead, Matkov Kot, 2017

(foto Miran Kambič, Rok Žnidaršič).
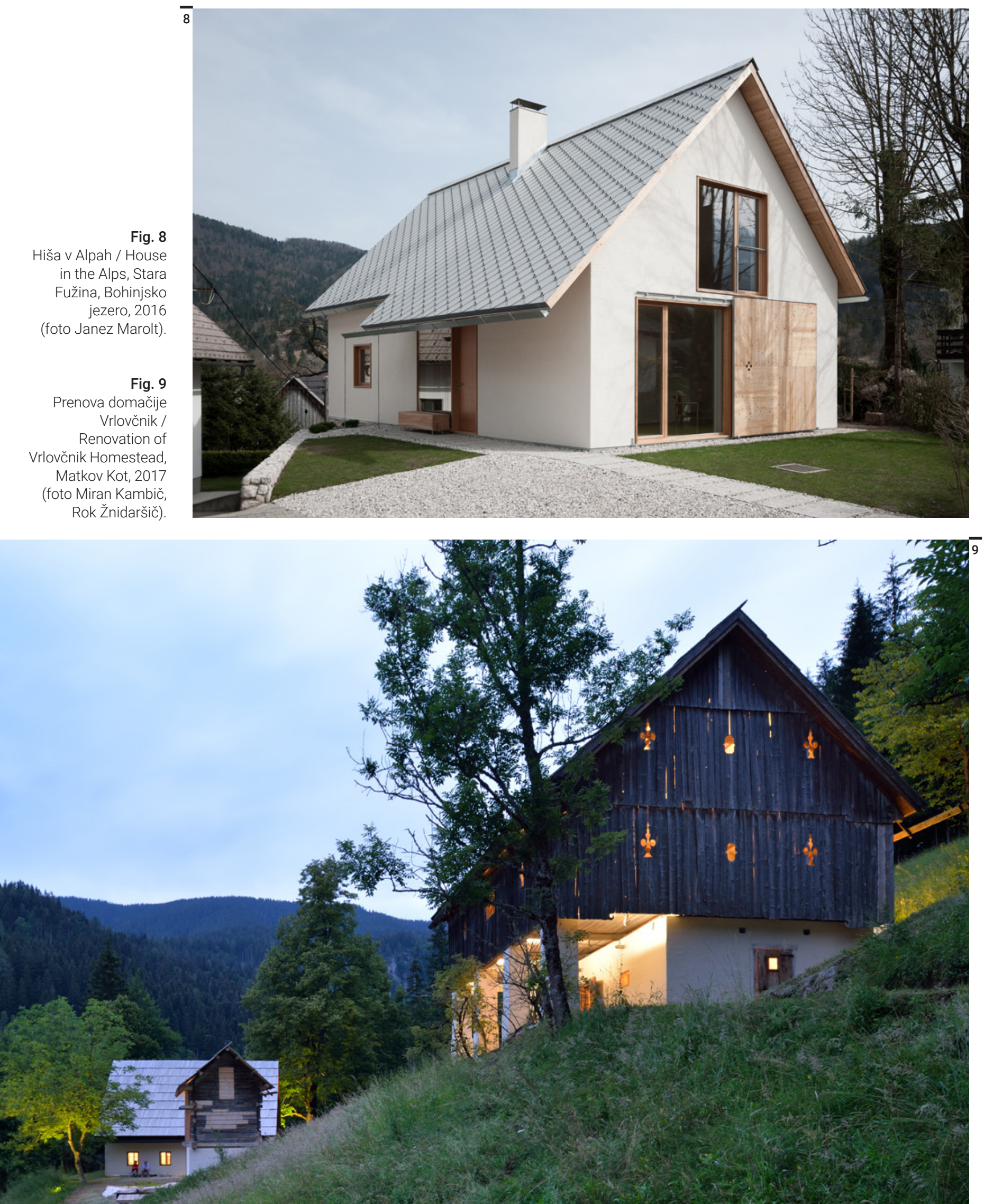
Stanovanjske in počitniške hiše / houses: dwelling and leisure

Prenova alpskega skednja / Alpine Barn Renovation, Bohinj, 2015

Arhitektura: OFIS arhitekti

Star alpski skednenj so arhitekti prenovili v počitniški apartma. Navzven ostaja nespremenjen, le leseni obod je na nekaterih mestih perforiran. V notranjost skednja pa je vstavljena lesena školjka z novimi bivalnimi prostori. Vsi elementi interierja, tla, stene in pohištvo, so iz brušene lokalne smreke. Na strehi je originalna kritina - špičak. Zelena rampa za spravilo sena je postala glavni vhod s teraso in vhodno verando.

Hiša v Alpah / House in the Alps, Stara Fužina, Bohinjsko jezero, 2016

Arhitektura: Tomaž Ebenšpanger, Meta Kutin

Nova, sodobno zasnovana hiša nagovarja tradicionalno okolje z interpretacijo značilnih lokalnih detajlov, prenesenih v sodoben material: novi žlebovi ohranjajo motiv starih lesenih, položenih na lesene kljuke. Različna globina napuščev sledi vaški pragmatičnosti, a od okolice izstopajo po svoji vitkosti, h kateri pripomoreta tanka vlaknocementna siva kritina in nosilna konstrukcija iz lesenih križno lepljenih plošč. Kljub sodobnim linijam, velikim steklenim površinam in vidnemu betonu se zdi, da hiša na svojem mestu stoji že od nekdaj.

Prenova domačije Vrlovčnik / Renovation of Vrlovčnik Homestead, Matkov Kot, 2017

Arhitektura: Medprostor: Rok Žnidaršič, Žiga Ravnikar, Jerneja Fischer Knap

Prenovljeni kompleks domačije sestavljo hiša, kašča, marof in kovačija. Vse stavbe so sanirane lupine novih programov. Z vključevanjem lokalnih izvajalcev, uporabo tradicionalnih materialov in obrtniških tehnik ter s premišljeno in občutljivo arhitekturno odelavo prenova prispeva k oživljanju zapuščenega področja in k ohranjanju kulturne krajine in identitete prostora. 